Article

\title{
The Impact of Disaster of a National Airline on the Nation's Tourism: An Empirical Investigation
}

\author{
Ting Fan ${ }^{1, *}$, Bo Pu ${ }^{2} \mathbb{C}$, Samart Powpaka ${ }^{3, *}$ and Liaogang Hao ${ }^{1}$ \\ 1 School of Economics and Management, Southwest Jiaotong University, Chengdu 610031, China; \\ haoliaogang@126.com \\ 2 College of Tourism, Sichuan Agricultural University, Chengdu 611830, China; ppuubo@hotmail.com \\ 3 School of Management and Economics, The Chinese University of Hong Kong, Shenzhen 518172, China \\ * Correspondence: tfan@swjtu.edu.cn (T.F.); powpaka@cuhk.edu.cn (S.P.)
}

Received: 25 January 2019; Accepted: 20 February 2019; Published: 26 February 2019

\begin{abstract}
This study contributes to the area of tourism research by investigating the process by which the air disaster of a national airline affects tourists' attitude and intention to fly the airline as well as attitude and intention to visit the country. A survey with potential Chinese tourists on visiting Malaysia and flying Malaysia Airlines was conducted. Results show that intention to visit Malaysia is positively affected by attitude toward visiting Malaysia and intention to fly Malaysia Airlines. Attitude toward visiting Malaysia is positively affected by attitude toward flying Malaysia Airlines and negatively by perceived risk of visiting Malaysia. Perceived risk of visiting Malaysia is, in turn, negatively affected by subjective knowledge about Malaysia and attitude toward flying Malaysia Airlines, and positively by perceived risk of flying Malaysia Airlines. Intention to fly Malaysia Airlines, on the other hand, is positively affected by attitude toward flying Malaysia Airlines. Attitude toward flying Malaysia Airlines is negatively affected by perceived risk of flying Malaysia Airlines, which is, in turn, positively affected by usefulness of (negative) public opinion. The theoretical contribution, managerial implications, limitations, and future research direction are also discussed.
\end{abstract}

Keywords: air disaster; subjective knowledge; usefulness of public opinion; perceived risk; attitude; purchase intention; Malaysia Airlines; Malaysia

\section{Introduction}

According to Aviation Benefits beyond Borders [1], tourism makes a significant contribution to the global economy. According to the article, tourism contributed almost 10\% to the world GDP (US\$ 2.2 trillion) in 2015 and provided over 108 million jobs globally. It is estimated that by 2024, the direct employment in the tourism industry will reach more than 126 million globally. In Malaysia, tourism has become the country's 6th largest economic pillar, and attracting tourists from the Chinese market is one of the country's key focus [2].

Air travel plays a critical role in supporting tourism. It has become an integral part of international tourism. The connectivity provided by international air transport facilitates the fast-growing global tourism industry. Aviation Benefits beyond Borders [1] estimates that over half of international tourists travel to their destination by air.

When visiting a foreign tourist destination, consumers are likely to consider the national airline of the country of destination because of the likely shorter travel time and more convenience in connecting flights. An important issue is whether or not problems with the national airline, especially airline disasters, negatively affect the foreign tourists' intention to use the airline as well as intention to visit 
the country. Although this kind of incident is rare, the tremendous negative impact of such an incident on the airline and the country [3] warrants an investigation of this type of incident.

Malaysia Airlines is such a national airline that experienced air disasters. The mysterious disappearance of Malaysia Airlines Flight MH370 (from Kuala Lumpur to Beijing on March 8, 2014) and the crash of Malaysia Airlines Flight MH317 (from Amsterdam to Kuala Lumpur on July 17, 2014) significantly affected the perceived risks in flying the airline among Chinese passengers as well as many other passengers making bookings in Europe, and as such significantly affected Malaysia Airlines' business [4]. Malaysia, which was ranked the 9th most-visited country in the world in 2010, slid to 12th in 2016 [3].

It has been four years since the two Malaysian Airlines' disasters in 2014. The effect of Malaysia Airlines Flight MH370 still seems to linger in Chinse people's mind. An interesting question is whether or not this air disaster still affects Chinese tourists' willingness to visit Malaysia by Malaysia Airlines, and if yes, how visiting Malaysia and flying Malaysia Airlines relate to each other.

The objective of this study is to investigated the process by which the air disaster of a national airline (i.e., Malaysia Airlines) affects tourists' attitude and intention to fly the airline as well as attitude and intention to visit the country (i.e., Malaysia). Specifically, this study proposed and empirically tested factors affecting the attitude and intention toward flying Malaysia Airlines, and factors affecting attitude and intention toward visiting Malaysia. To achieve this objective, a qualitative research with potential Chinese passengers augmented by literature review was conducted to come up with the conceptual model for this study.

The next section discussed the conceptualization of the conceptual model and hypothesis. This is followed by research methodology. Section 4 discusses the results of the study. The final conclusion section discusses theoretical contribution, managerial implications, limitations, and future research direction.

\section{Conceptual Model and Hypotheses}

Review of literature reveals that, surprisingly, there is no study that directly addresses the issue of air disasters and their impacts on the willing to fly the airlines and visiting the countries of origin of the airlines. As such, a model conceptualization approach used by Zeithaml [5] was adopted to conceptualize the conceptual model for this study. The steps in the model conceptualization process are discussed in the next section.

\subsection{Model Conceptualization Process}

As suggested Zeithaml [5], insights from an exploratory study with potential Chinese tourists and review of relevant literature were combined into a conceptual model that conceptualizes the perceptions, attitudes, and intentions toward flying Malaysia Airlines and toward visiting Malaysia. Specifically, a focus group interview was conducted to generate qualitative data that served as the basis for model conceptualization and research hypothesis formulation. Based on the concepts and their relationships identified in the qualitative research, literature review was conducted to identify appropriate conceptual frameworks to conceptualize the phenomenon, and then to find literature to support the relationships among the constructs. The model conceptualization process is discussed in detail below.

\subsubsection{The Exploratory Study}

The focus group interview was based on an interview guideline, and the questions were semi-structured to allow additional insights. To guarantee the validity of the interview, the selection of interviewees was concentrated on candidates who have certain knowledge about aviation disaster, for example know or at least heard about the MH370 accident, fly often for business or vacation, and have the possibility to fly international airlines. In addition, the participants should be able to clearly and fluently express their opinions. Thus, a focus group interview of eight Chinese tourists 
with an education level of undergraduates and above who plan to visit foreign tourist destinations was conducted. The participants included four males and four females between the age of 25 and 55 and all had visited foreign tourist destination on individual visas. To control the process of the focus group interview, the location was situated in a place with minimum distraction (the office of the moderator or participant) to secure the continuity and fluency of the focus group interview. The discussion centered on Malaysia as the tourist destination and then Malaysia Airlines as the airline for visiting Malaysia. The moderator first expressed his gratitude for the interviewers to take part in the focus group interview, and then presented a brief introduction of the MH370 air disaster and the purpose of the interview. Questions covering such topics as the advantages and disadvantages of visiting Malaysia and flying Malaysia Airlines, the perceived risked of choosing airplanes as the transportation for business or vacation, and factors affecting the interviewers' choice of transportation and vacation destination were then discussed along the process.

The focus group interview revealed following findings:

- There was a perceived risk (i.e., physical risk) in visiting Malaysia because of news about a Chinese tourist being kidnapped in Sabah, Malaysia. This perceived risk negatively the subjects' affected attitude toward visiting Malaysia and intention to visit Malaysia.

- There was still a perceived risk (i.e., physical risk) in flying Malaysia Airlines because of the MH370 incident. This perceived risk negatively affected the subjects' attitude toward flying Malaysia Airlines to Malaysia and intention to fly Malaysia Airlines.

- Favorable attitude toward flying Malaysia Airlines seems to reduce perceived risk in visiting Malaysia and increase the subjects' positive attitude toward visiting Malaysia.

- The subjects' subjective knowledge about the aviation/airlines and subjective knowledge about Malaysia seem to reduce perceived risk in flying Malaysia Airlines and perceived risk in visiting Malaysia, respectively.

- Perceived usefulness of (negative) public opinions about the Malaysia Airlines seems to affect and increase perceived risk in flying Malaysia Airlines and perceived risk in visiting Malaysia.

Based on the findings from the focus group interview, a literature review was conducted to identify an appropriate conceptual framework as well as to find empirical support for the relationship among the constructs.

\subsubsection{The Conceptual Frameworks}

Based on the findings from the focus group interview, a conceptual framework is needed to link all the concepts/constructs identified from the focus interview together into a coherent scheme of relationships. Since beliefs and attitudes were identified in the focus group interview, attitudinal models were reviewed to identify the appropriate framework for conceptualizing the conceptual model for this study. The literature review identified the dual mediation model [6] as the appropriate conceptual framework to conceptualize the conceptual model for this study.

\subsubsection{The Dual Mediation Model}

MacKenzie, Lutz, and Belch [6] derived the dual mediation model from the joint cognitive structure of communication effects [7] and the elaboration likelihood model [8] to explain the role of attitude toward the ad as the mediator of advertising effectiveness in their empirical study [9]. The dual mediation model posits that an attitude toward an attitudinal object can affect the cognition as well as the attitude of another attitudinal object $[6,8]$. Figure 1 shows the overview of the dual mediation model. 


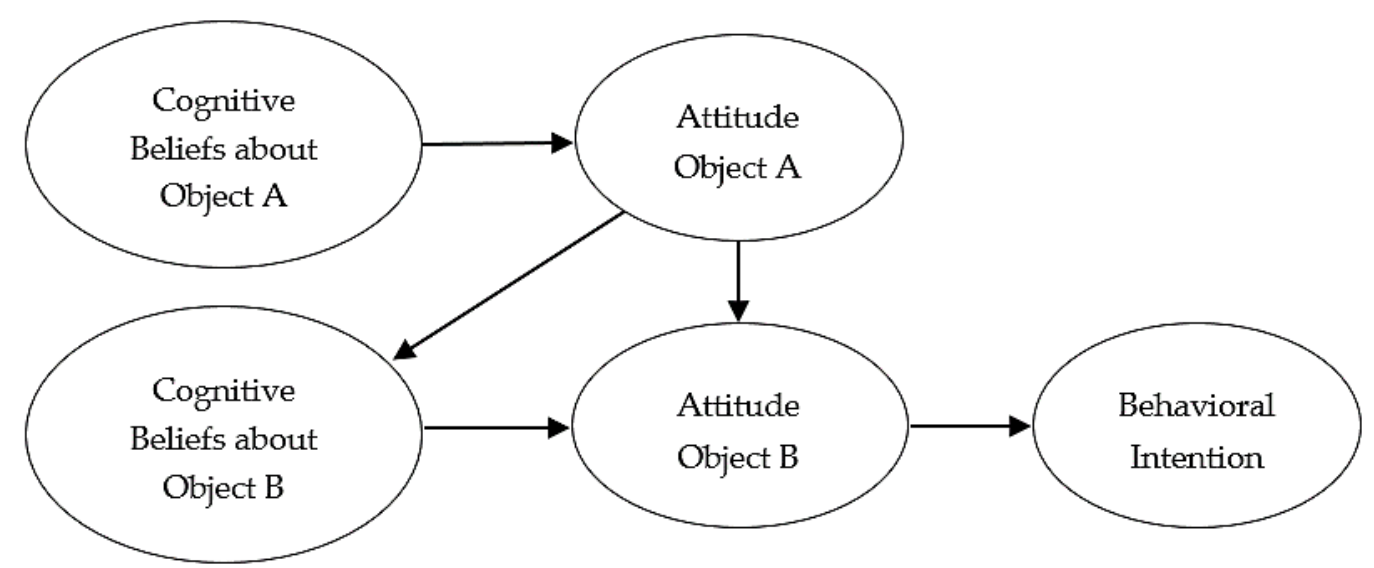

Figure 1. Dual mediation model.

The dual mediation hypothesis has been used as the conceptual framework in several empirical studies. These studies mainly concern the role of attitude toward the ad as the mediator between ad cognitions and brand cognitions and attitude toward the brand in the context of advertising. Some of the exemplar applications of the dual mediation model include the comparison of four competing models explaining the mediating role of attitude toward the ad [6], the replication and extension of MacKenzie, Lutz, and Belch's [6] four competing models [10], the reexamination and extension of MacKenzie, Lutz, and Belch's [6] four competing models in online advertising context [11], website effectiveness [12], and the impact of corporate credibility and celebrity credibility on consumer reaction to advertisements and brands [13].

\subsection{Conceptual Model}

Based on the findings from the focus interview and the conceptual framework (i.e., the dual mediation model), the conceptual model for this study is shown in Figure 2. According to the conceptual model, intention to fly Malaysia Airlines to Malaysia is positive affected by attitude toward flying Malaysia Airlines. Attitude toward flying Malaysia Airlines is negatively affected by perceived risk of flying Malaysia Airline, which is, in turn, negatively affected by subjective knowledge about aviation and positively by usefulness of (negative) public opinion. Intention to visit Malaysia is positively affected by intention to fly Malaysia Airlines and attitude toward visiting Malaysia. Attitude toward visiting Malaysia is, in turn, negatively affected by perceived risk of visiting Malaysia and positively by attitude toward flying Malaysia Airlines. Finally, perceived risk of visiting Malaysia is negatively affected by subjective knowledge about Malaysia and attitude toward flying Malaysia Airlines, and positively by perceived usefulness of (negative) public opinion about Malaysia Airlines and perceived risk of flying Malaysia Airlines. Each of the proposed relationships is discussed below: 


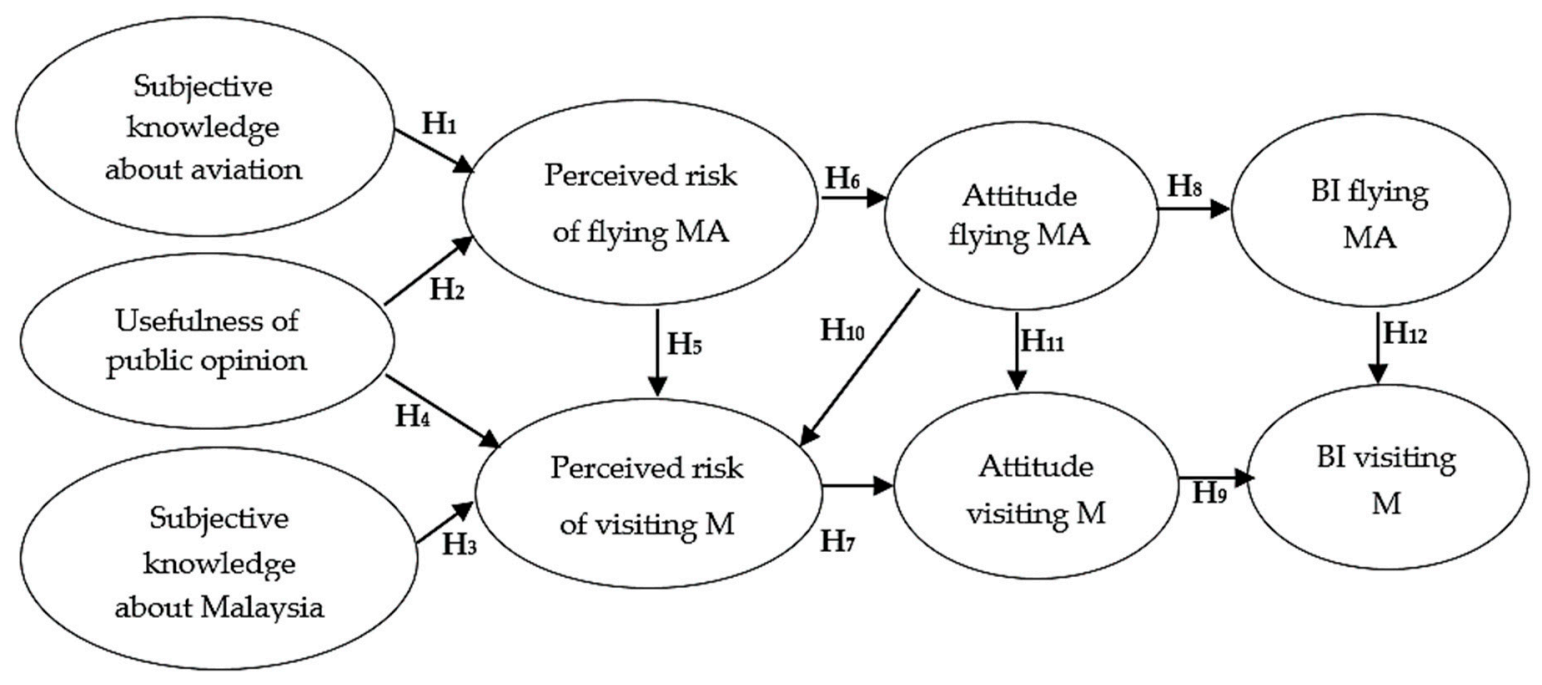

Figure 2. Conceptual model.

2.2.1. Subjective Knowledge, Usefulness of Public Opinion, and Perceived Risk

Subjective Knowledge

Consumer knowledge is defined as the extent of consumer experiences and familiarity towards a product before external search [14-17]. Past relevant studies stated that consumer knowledge is not only an primary influencer of consumer behavior but also of consumer risk perception [18-20]. There are two distinct components of consumer knowledge: subjective knowledge, a person's perception of the amount of a specific product information storied in his or her memory $[15,21,22]$, and objective knowledge, which refers to the actual amount of accurate information stored in his or her memory $[15,21]$. This distinction is important as it indicates that each knowledge type has different effects on consumer information processing and subsequent consumer behaviors [18,22-24].

Past researchers have found that subjective knowledge is significantly related to decision making, more so than objective knowledge [24]. Similarly, compared to objective knowledge, subjective knowledge plays a more important role in purchase intentions' prediction [22] and in purchasing related behaviors' motivation [25]. This is due to the fact that consumers who have higher subjective knowledge level feel less confused about their choice, implying that subjective knowledge may lead to less perceived risk and more self-confidence in purchase decision making [26]. Previous research also showed that subjective knowledge as a predictor of consumer purchase satisfaction [24] and a motivator of consumer consumption $[27,28]$. Subjective knowledge has been concluded from empirical testing to play a more important role in the definition of knowledge because it may influence consumer's perception of their ability to process information [29]. Moreover, according to Perrouty, d'Hauteville, and Lockshin [30], subjective knowledge is critical in shaping consumers' behavior and is a suitable basic factor in the determination of whether a consumer is an expert or a novice.

In sum, past studies emphasized consumer subjective knowledge is a strong predictor of consumer behavior, thus plays an important role in shaping consumer behaviors, i.e., information search and information processing in particular [18,21,31]. As such, Chinese tourists' subjective knowledge about aviation should affect their information processing about flying Malaysia Airlines and consequently affects their beliefs and attitude toward flying Malaysia Airlines. Their subjective knowledge about Malaysia should affect their information processing about visiting Malaysia and consequently affects their beliefs and attitude toward visiting Malaysia.

\section{Usefulness of Public Opinion}

When consumers make high-involvement purchase decisions, they are likely to conduct external search from both marketer-controlled sources such as advertisements and non-marketer-controlled 
sources such as word of mouth and public opinion [32]. The additional information obtained from external search generally enables consumers to make purchase decisions easier.

Public opinion is a complex but common phenomenon. With the rapid development of information and communication technology, public opinion has become more active than ever, and the resultant upheavals of public opinion has become acknowledged and studied in the area of marketing $[33,34]$. It is reasonable to contend that consumers can find public opinions from the Internet in any issue or topic. The extent to which the consumers evaluate online review's helpfulness in the purchase decision process is defined as the usefulness of online review or public opinion [35]. Herrero et al. [36] proposed that review information generated by users is able to affect other users' behavior if the information is considered useful and the source is credible. Past studies stated perceived usefulness of public opinion as a key element in the use of technology, and the strength of belief in the usefulness leads to higher frequency of online communication [37-39].

From the focus group, a decision to choose a foreign tourist destination for vacation and an airline for the destination is likely to be a high-involvement decision making for Chinese. Chinese tourists generally consult their friends and relatives about the destination they plan to visit. They also browse for public opinion on the websites about the tourist destination. They tend to incorporate word of mouth and public opinion that they deem to be credible and as such useful in their decision making.

Browsing of public websites for Malaysia Airlines showed that public opinions about Malaysia Airlines are still mostly negative. Previous studies suggest that compared to positive online reviews negative ones have greater influence on consumer purchase decision making [35,40], and according to Davis et al. [37] perceived usefulness is likely to affect consumer purchase decision, potential travelers find negative online reviews to be more useful than positive ones [41]. As such, the extent or degree to which Chinese tourists believe that the (negative) public opinion about Malaysia Airlines is useful should significantly shapes their attitude and purchase decisions.

\section{Perceived Risk}

Perceived risk is brought in to the consumer behavior context in the 1960s [42]. The literature defines perceived risk as a two-dimensional construct, i.e., uncertainty and negative consequences [42,43]. In other words, due to the unknown degree of accuracy in the consequences of use and probability of the consequences actually occurring, the concept of perceived risk in marketing (i.e., purchasing and consumption) correlates closely with partial ignorance [18,42].

Consumers normally decide to make their purchase after seeing, touching or trying out the product, but this is not be the case for tourism industry products due to the intangibility of the product characteristics, as a result, perceived risk is found to significantly affect consumer purchase decisions [44,45]. In marketing, several distinctive types of perceived risk associated with the acquisition and use of products have been identified, including financial risk, performance risk, physical (or safety) risk, psychological risk, and social risk [46]. Review of past literature shows that perceived risk does not have explanatory power in low-involvement purchases [32]. However, it is likely to be a key factor that determines consumer decisions in high-involvement purchases [18]. Since decisions to choose a tourist destination and an airline to the destination are likely to be high-involvement decisions for Chinese tourists, it is very likely that perceived risks regarding flying Malaysia Airlines and perceived risk regarding visiting Malaysia should affect their purchase decisions.

Results from the focus group interview indicated that subjective knowledge is likely to have negative on perceived risks while usefulness of public opinion is likely to have positive impact on perceived risks. Past studies supports the focus group result, Jin and Han [26] pointed out that consumers with higher subjective knowledge level usually feel less confused about their choice of product, which implies that higher subjective knowledge lead to less perceived risk. Casaló, et al. [41] suggests that potential travelers find negative online reviews to be more useful, which implies negative consumer perception may lead to doubt more about their choice. Based on the above discussion, the following hypotheses are proposed: 
H1: Subjective knowledge about aviation negatively affects perceived risk of flying Malaysia Airlines.

H2: Usefulness of (negative) public opinion about Malaysia Airlines positively affects perceived risk of flying Malaysia Airlines.

H3: Subjective knowledge about Malaysia negatively affects perceived risk of visiting Malaysia.

H4: Usefulness of (negative) public opinion positively affects perceived risk of visiting Malaysia.

H5: Perceived risk of flying Malaysia Airlines positively affects perceived risk of visiting Malaysia.

\subsubsection{Perceived Risk, Attitude, and Purchase Intention}

Attitude

Attitude is consumer's overall evaluate of an object [47]. Attitude toward an attitudinal object is defined as the overall evaluation, in a favorable or unfavorable way, toward the attitudinal objective [48,49]. According to Ajzen and Fishbein [48] and Fishbein and Ajzen [49], attitude toward an attitudinal object is a function of cognitive beliefs about the attitudinal object. Perceived risk of an attitudinal objective is a perception or belief about the attitudinal object, and as such, should shape attitude toward the attitudinal object.

Previous studies also suggest a positive attitude lead to consumer's continuous preference towards a brand, and significantly influences consumer's purchase intention and willingness to pay a premium price [50-52]. Based on the theory of reasoned action, Summers et al. [53] proposed attitude is one of the dominant predictors of consumer purchase intention, and the purchase intention is high when attitude is favorable. The above discussions show that attitude is the primary determinant of consumer purchase intention [54].

Purchase intention

Purchase intention is the propensity or likelihood to buy the product. Consumer's purchase intention is a primary factor in forecasting consumer behavior [55]. In marketing studies, attitude and purchase intention exhibit an inseparable relationship [56]. Shen [57] argues that a set of determinants, for example attitudes, subjective norms, and perceived behavioral control tend to influence the purchase intention of customer. Duart and Amaro [58] also found that intention to purchase travel products is determined by attitude and percieved risk. According to Ajzen and Fishbein [48] and Fishbein and Ajzen [49], behavioral intention is a function of attitude toward the behavior. In marketing context, intention to buy a product or brand is a function of attitude toward the product or brand.

Since perceived risk is a belief held by consumers, the following hypotheses regarding the relationship between perceived risk of flying Malaysia Airlines and attitude toward flying Malaysia Airlines and that between perceived risk of visiting Malaysia and attitude toward visiting Malaysia are proposed:

H6: Perceived risk of flying Malaysia Airlines negatively affects attitude toward flying Malaysia Airlines.

H7: Perceived risk of visiting Malaysia negatively affects attitude toward visiting Malaysia.

The following hypotheses are proposed for the relationship between attitude toward flying Malaysia Airlines and intention to fly Malaysia Airlines and that between attitude toward visiting Malaysia and intention to visit Malaysia:

H8: Attitude toward flying Malaysia Airlines positively affects intention to fly Malaysia Airlines.

H9: Attitude toward visiting Malaysia positively affects intention to visit Malaysia.

The focus group interview revealed that attitude toward flying Malaysia Airlines seems to have impact on perceived risk of visiting Malaysia and attitude toward visiting Malaysia. Using the dual 
mediation model (i.e., an attitude toward an attitudinal object can affect the cognition as well as the attitude of another attitudinal object) as framework, the following hypotheses are proposed:

H10: Attitude toward flying Malaysia Airlines negatively affects perceived risk of visiting Malaysia.

H11: Attitude toward flying Malaysia Airlines positively affects attitude toward visiting Malaysia.

Finally, extending on the dual mediation model, the following hypothesis regarding the relationship between intention to fly Malaysia Airlines and intention to visit Malaysia is proposed:

H12: Intention to fly Malaysia Airlines positively affects intention to visit Malaysia.

\section{Methodology}

\subsection{Research Design}

The research design used in this study is sample survey. The rationale for choosing sample survey as the research design, which is a correlational study, is based on the fact that all the constructs in the conceptual model are measurable and the hypothesized relationships among these constructs are to be tested. The study utilized a self-administered online survey to collect data. A professional internet research website (http:/ / www.wjx.cn) is used for the data collection, the website randomly selects participants from its online panel to complete the questionnaire during the first two-year search for Flight MH370.

\subsection{Sample and Data Collection}

Data were collected from Chinese subjects who were planning vacation overseas via self-administered questionnaire. According to Leohlin [59], the number of survey subject for the structural equation modeling approach should be no less than 200, thus a total of 313 useable questionnaires were obtained. In terms of gender, there were 170 males (54.3\%) are 143 females (45.7\%). In terms of age, 227 of them were $19-29$ years old ( $72.5 \%)$, 71 were $30-39$ years old $(22.7 \%)$, 11 of them were $40-49$ years old (3.5), and 3 of them were 50-59 years old (1.0\%). In terms of marital status, 189 of them were single $(60.4 \%), 95$ of them were married $(30.4 \%)$, and 29 of them were cohabit or other $(9.3 \%)$. In terms of education, 2 of them were secondary school graduates $(0.6 \%), 48$ of them were currently college/university students $(15.3 \%), 76$ of them were college/university graduates (24.3\%), and 187 of them were postgraduate or higher (59.7\%). In terms of annual income, 131 of them earn below RMB 20,000 (41.9\%), 20 of them earn between RMB 20,000 and 39,999 (6.4\%), 20 of them earn between RMB 40,000 and 59,999 (6.4\%), 34 of them earn between RMB 60,000 and 79,999 (10.9\%), 29 of them earn between RMB 80,000 and 99,999 (9.3\%), 79 of them earn over RMB 100,000 (25.2\%). In terms of occupation, 134 of them were college and postgraduate students $(42.8 \%), 51$ of them were managers $(16.3 \%), 37$ of them were in education $(11.8 \%)$, and the rest of them were professionals such as engineers, physicians, information technologists (29.1\%). See Table 1 for demographic profile of the subjects. 
Table 1. Demographic profile of respondents.

\begin{tabular}{|c|c|c|}
\hline Demographic Categories & Frequency & $\%$ \\
\hline \multicolumn{3}{|l|}{ Gender } \\
\hline Male & 170 & 54.3 \\
\hline Female & 143 & 45.7 \\
\hline \multicolumn{3}{|l|}{ Age } \\
\hline Under 18 or 18 & 1 & 0.3 \\
\hline $19-29$ & 227 & 72.5 \\
\hline $30-39$ & 71 & 22.7 \\
\hline $40-49$ & 11 & 3.5 \\
\hline $50-59$ & 3 & 1.0 \\
\hline \multicolumn{3}{|l|}{ Marital status } \\
\hline Single & 189 & 60.4 \\
\hline Cohabit & 25 & 8.0 \\
\hline Married & 95 & 30.4 \\
\hline Other & 4 & 1.3 \\
\hline \multicolumn{3}{|l|}{ Educational level } \\
\hline Secondary school & 2 & 0.6 \\
\hline College or university & 48 & 15.3 \\
\hline University graduate & 76 & 24.3 \\
\hline Postgraduate and above & 187 & 59.7 \\
\hline \multicolumn{3}{|l|}{ Annual income (RMB) } \\
\hline Under 20,000 & 131 & 41.9 \\
\hline $20,000-39,999$ & 20 & 6.4 \\
\hline $40,000-59,999$ & 20 & 6.4 \\
\hline $60,000-79,999$ & 34 & 10.9 \\
\hline $80,000-99,999$ & 29 & 9.3 \\
\hline 100,000 or more & 79 & 25.2 \\
\hline \multicolumn{3}{|l|}{ Occupation } \\
\hline Student & 134 & 42.8 \\
\hline Engineer & 19 & 6.1 \\
\hline Business & 51 & 16.3 \\
\hline Education & 37 & 11.8 \\
\hline Medicine & 10 & 3.2 \\
\hline Information technology & 17 & 5.4 \\
\hline Design & 4 & 1.3 \\
\hline Scientist & 8 & 2.6 \\
\hline Executive & 18 & 5.8 \\
\hline Self-employed & 6 & 1.9 \\
\hline Other & 9 & 2.9 \\
\hline
\end{tabular}

\subsection{Operationalization/Measures}

There were nine constructs in the conceptual model and, as such, there were nine scales in the questionnaire: subjective knowledge about aviation, subjective knowledge about Malaysia, perceived usefulness of (negative) public opinion about Malaysia Airlines and Malaysia, perceived risk of flying Malaysia Airlines, perceived risk of visiting Malaysia, attitude toward flying Malaysia Airlines, attitude toward visiting Malaysia, intention to fly Malaysia Airlines, and intention to visit Malaysia. Some of these scales were derived from the focus group interview while others were derived from past studies. Each of the scales is discussed below.

\subsubsection{Subjective Knowledge about Aviation}

Subjective knowledge about aviation is defined in this study as a person's perception of the amount of information regarding aviation stored in his or her memory. The scale is derived from Flynn and Goldsmith's [22] scale. Subjective knowledge about aviation is measured by a three-item, seven-point Likert scale. The example sample items are "I know pretty much about aviation "and" I do not feel very knowledgeable about aviation (reverse score)". 


\subsubsection{Subjective Knowledge about Malaysia}

Subjective knowledge about Malaysia is defined in this study as a person's perception of the amount of information regarding Malaysia stored in his or her memory. The scale is derived from Flynn and Goldsmith's [22] scale. Subjective knowledge about Malaysia is measured by a three-item, seven-point Likert scale. The example sample items are "I know pretty much about Malaysia "and" I do not feel very knowledgeable about Malaysia (reverse score)".

\subsubsection{Usefulness of Public Opinion about Malaysia Airlines}

Usefulness of public opinion about Malaysia Airlines is defined in this study as the extent that a person perceives the public opinion about Malaysia Airlines to be useful for his or her decision. The scale is derived from Davis's [37] perceived usefulness scale. Usefulness of public opinion about Malaysia Airlines is measured by a four-item, seven-point Likert scale. The example sample items are "I think the public opinion about Malaysia Airlines is very useful" and "Public opinions about Malaysia Airlines can help me save time effectively in finding information".

\subsubsection{Perceived Risk of Flying Malaysia Airlines}

Perceived risk of flying Malaysia Airlines is defined in this study as a person's perception of the extent of risk incurred from flying Malaysia Airlines. The scale is derived from Forsythe and Shi's [60] scale. Perceived risk of flying Malaysia Airlines is measured by a two-item, seven-point Likert scale. The example sample items are "I do not trust that Malaysia Airlines will be safe" and "I do not trust that Malaysian airlines will provide me with a safe flight".

\subsubsection{Perceived Risk of Visiting Malaysia}

Perceived risk of visiting Malaysia Airlines is defined in this study as a person's perception of the extent of risk incurred from visiting Malaysia. The scale is derived from Forsythe and Shi's [60] scale. Perceived risk of visiting Malaysia is measured by a two-item, seven-point Likert scale. The example sample items are "I do not trust that Malaysia will be safe" and "I do not trust that Malaysia will provide me with a safe tourism environment".

\subsubsection{Attitude toward Flying Malaysia Airlines}

Attitude toward flying Malaysia Airlines is defined in this study as a person's overall favorability toward flying Malaysia Airlines. The scale is derived from Jang and Namkung's [61] emotional response scale. Attitude toward flying Malaysia Airlines is measured by a three-item, seven-point Likert scale. The example sample items are "My emotion toward Malaysia Airline is anger" (reversed scale) and "My overall feeling toward flying Malaysia Airlines is distress" (reversed scale).

\subsubsection{Attitude toward Visiting Malaysia}

Attitude toward visiting Malaysia is defined in this study as a person's overall favorability toward visiting Malaysia Airlines. The scale is derived from Jang and Namkung's [61] emotional response scale. Attitude toward visiting Malaysia is measured by a three-item, seven-point Likert scale. The example sample items are "My emotion toward visiting Malaysia is anger" (reversed scale) and "My overall feeling toward visiting Malaysia is distress" (reversed scale).

\subsubsection{Intention to Fly Malaysia Airlines}

Intention to fly Malaysia Airlines is defined in this study as a person's propensity to fly to Malaysia by Malaysia Airlines. The scale is derived from Jalilvand et al.'s [62] scale. Intention to fly Malaysia Airlines is measured by a three-item, seven-point Likert scale. The example sample items are "I predict I will fly Malaysia Airlines in the future" and "I would fly Malaysia Airlines rather than any other airline". 


\subsubsection{Intention to Visit Malaysia}

Intention to visit Malaysia is defined in this study as a person's propensity to visit Malaysia for vacation. The scale is derived from Jalilvand et al.'s [62] scale. Intention to visit Malaysia for vacation is measured by a three-item, seven-point Likert scale. The example sample items are "I predict I will visit Malaysia in the future" and "I would visit Malaysia rather than any other tourism destination".

For the complete measures, please see Appendix A.

\subsection{Data Analysis}

To test the hypothesized relationships between the constructs specified in the conceptual model, a structural equation modeling approach was employed. The data were input into PRELIS 2 [63], which generated the covariance matrix for the structural equation analysis. The matrix was then input into LISREL 8 [64] to examine the fitness of the model and to test the causal relationships specified in the conceptual model [65]. The structural equation model is shown in Figure 3.

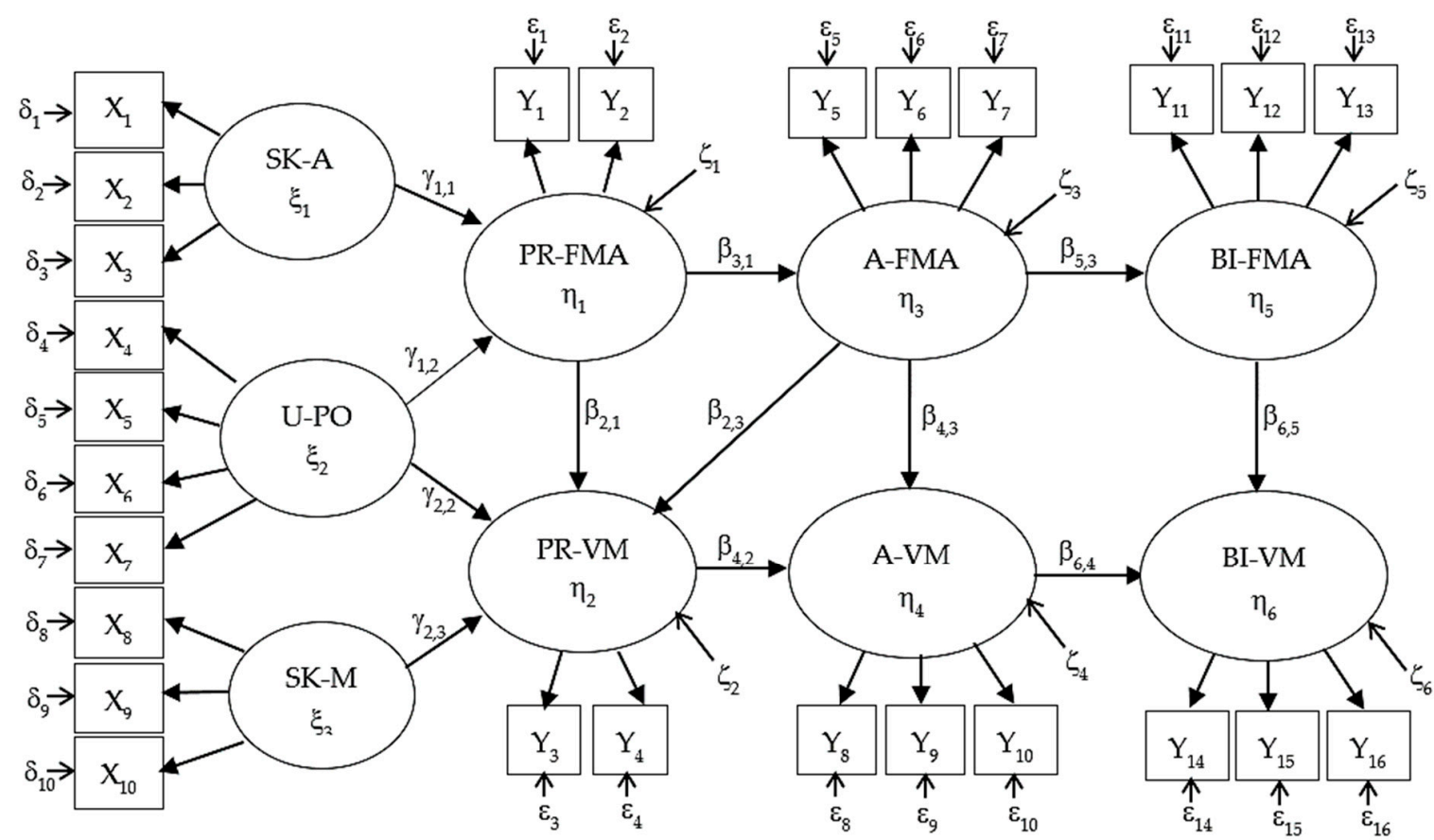

Figure 3. Structural equation model.

\section{Results and Discussion}

This section first reports the measurement model results. This is followed by the structural model results. Finally, the findings and unsupported hypotheses are discussed.

\subsection{Measurement Model Results}

The measurement model specifies how the latent variables are measured in terms of the observed variables. It also describes the measurement properties (reliabilities and validities) of the scales used. A good measurement model should have high reliabilities, high and statistically significant indicator coefficients (i.e., $\lambda x s$ and $\lambda y s$ ), and high construct validities (i.e., convergent validity and discriminant validity). Note that the construct validities are assessed by the methods suggested by Fornell and Larcker [66]. Table 2 shows the standardized indicator coefficients, reliabilities, and proportion-of-variance extracted of the constructs in the conceptual model. Each of the measurement properties is discussed in the following sections. 
Table 2. Measurement model results.

\begin{tabular}{|c|c|c|c|}
\hline Constructs and Indicators & Standardized Factor Loadings & Reliability/Item $\mathbf{R}^{2}$ & Proportion of Variance Extracted \\
\hline Subjective Knowledge-Aviation $\left(\xi_{1}\right)$ & & 0.815 & 0.6000 \\
\hline X1 (SUBJKNOWL-AVIATION 1) & $0.71^{\mathrm{a}, \mathrm{b}}$ & 0.51 & \\
\hline X2 (SUBJKNOWL-AVIATION 2) & $0.83^{\mathrm{b}}$ & 0.69 & \\
\hline X3 (SUBJKNOWL-AVIATION 3) & $0.77^{\mathrm{b}}$ & 0.60 & \\
\hline Usefulness of Public Opinion $\left(\xi_{2}\right)$ & & 0.875 & 0.6375 \\
\hline X4 (USEFULNESS 1) & $0.82^{a, b}$ & 0.67 & \\
\hline X5 (USEFULNESS 2) & $0.81^{\mathrm{b}}$ & 0.66 & \\
\hline X6 (USEFULNESS 3 ) & $0.82^{b}$ & 0.67 & \\
\hline X7 (USEFULNESS 4) & $0.74^{\mathrm{b}}$ & 0.55 & \\
\hline Subjective Knowledge-Malaysia $\left(\xi_{3}\right)$ & & 0.887 & 0.7333 \\
\hline X8 (SUBJKNOWL-MALAYSIA 1) & $0.80^{\mathrm{a}, \mathrm{b}}$ & 0.64 & \\
\hline X9 (SUBJKNOWL-MALAYSIA 2) & $0.90^{\mathrm{b}}$ & 0.82 & \\
\hline X10 (SUBJKNOWL-MALAYSIA 3) & $0.86^{\mathrm{b}}$ & 0.74 & \\
\hline Perceived Risk-Flying Malaysia Airlines $\left(\eta_{1}\right)$ & & 0.899 & 0.8200 \\
\hline Y1 (RISK-FLYING MS 1) & $0.86^{\mathrm{a}, \mathrm{b}}$ & 0.74 & \\
\hline Y2 (RISK-FLYING MS 2) & $0.95^{\mathrm{b}}$ & 0.90 & \\
\hline Perceived Risk-Visiting Malaysia $\left(\eta_{2}\right)$ & & 0.851 & 0.7450 \\
\hline Y3 (RISK-VISTING MALAYSIA 1) & $0.83^{a, b}$ & 0.69 & \\
\hline Y4 (RISK-VISTING MALAYSIA 2) & $0.89^{b}$ & 0.80 & \\
\hline Attitude toward Flying Malaysia Airlines $\left(\eta_{3}\right)$ & & 0.774 & 0.5500 \\
\hline Y5 (ATTITUDE-FLYING MS 1) & $0.67^{a, b}$ & 0.45 & \\
\hline Y6 (ATTITUDE-FLYING MS 2) & $0.89^{\mathrm{b}}$ & 0.79 & \\
\hline Y7 (ATTITUDE-FLYING MS 3) & $0.64^{\mathrm{b}}$ & 0.41 & \\
\hline Attitude toward Visiting Malaysia $\left(\eta_{4}\right)$ & & 0.903 & 0.7533 \\
\hline Y8 (ATTIUTDE-VIST MALAYSIA 1) & $0.83^{a, b}$ & 0.68 & \\
\hline Y9 (ATTIUTDE-VIST MALAYSIA 2) & $0.88^{b}$ & 0.82 & \\
\hline Y10 (ATTIUTDE-VIST MALAYSIA 3) & $0.89^{b}$ & 0.78 & \\
\hline Intention-Flying Malaysia Airlines $\left(\eta_{5}\right)$ & & 0.896 & 0.7400 \\
\hline Y11 (INTENTION-FLYING MS 1) & $0.85^{\mathrm{a}, \mathrm{b}}$ & 0.73 & \\
\hline Y12 (INTENTION-FLYING MS 2) & $0.82^{b}$ & 0.67 & \\
\hline Y13 (INTENTION-FLYING MS 3) & $0.92^{\mathrm{b}}$ & 0.85 & \\
\hline Intention-Visiting Malaysia $\left(\eta_{6}\right)$ & & 0.897 & 0.7633 \\
\hline Y14 (INTENTION-VISIT MALAYSIA 1) & $0.90^{\mathrm{a}, \mathrm{b}}$ & 0.83 & \\
\hline Y15 (INTENTION-VISIT MALAYSIA 2) & $0.77^{\mathrm{b}}$ & 0.60 & \\
\hline Y16 (INTENTION-VISIT MALAYSIA 3) & $0.93^{b}$ & 0.87 & \\
\hline
\end{tabular}

${ }^{a}$ Fixed at 1.00 in the non-standardized solution; ${ }^{\mathrm{b}} p<0.001,1$-tailed t-test.

\subsubsection{Reliability Analysis}

The reliability (i.e., Cronbach Alpha) of all the constructs exceeded 0.7, which is the threshold that was recommended by Nunnally [67] for exploratory research. Specifically, the reliabilities of subjective knowledge about aviation, subjective knowledge about Malaysia, usefulness of public opinion, perceived risk of flying Malaysia Airlines, perceived risk of visiting Malaysia, attitude toward flying Malaysia Airlines, attitude toward visiting Malaysia, intention to fly Malaysia Airlines, and intention to visit Malaysia are $0.815,0.887,0.875,0.899,0.851,0.774,0.903,0.896$, and 0.897 , respectively.

\subsubsection{Validity Analysis}

All of the constructs have acceptable convergent validity as all of the standardized indicator coefficients except two $(\lambda y 1,3=0.67$ and $\lambda y 3,3=0.64)$ exceeded the minimum level of 0.7 , the threshold recommended by Fornell and Lacker [66]. The more conservative proportion-of-variance-extracted index [66], which indicated that the amount of variance that is captured by a construct in relation to the amount of variance that is caused by the measurement error, also showed that all of the constructs had a high convergent validity (ranging from 0.5500 to 0.8200 ). All of the indices exceeded the minimal standard of 0.50 [66], which indicated that the variance captured by the construct exceeded the variance that was caused by the measurement error.

The discriminant validity among the nine scales was assessed by comparing the proportion-of-variance-extracted indices of the two constructs in each pair of constructs with the square of the correlation coefficient between the two constructs [66]. The result of this assessment supported the discriminant validity of all of the constructs in the conceptual model. Specifically, the proportion-of-variance-extracted indices of any pair of constructs were higher 
than the square of the correlation coefficient between the two constructs for every possible pair. The proportion-of-variance-extracted indices of the nine constructs and the correlation matrix of the nine constructs are shown in Table 3.

Table 3. Correlation matrix of the latent variables.

\begin{tabular}{|c|c|c|c|c|c|c|c|c|c|c|}
\hline Latent Variables & POVEI & RISK-A & RISK-M & A-FM & $\mathrm{A}-\mathrm{VM}$ & BI-FM & BI-VM & SK-A & SK-M & U-PO \\
\hline RISK-A & 0.8200 & 1.00 & & & & & & & & \\
\hline RISK-M & 0.7450 & 0.58 & 1.00 & & & & & & & \\
\hline A-FM & 0.5500 & -0.69 & -0.58 & 1.00 & & & & & & \\
\hline $\mathrm{A}-\mathrm{VM}$ & 0.7533 & -0.40 & -0.55 & 0.47 & 1.00 & & & & & \\
\hline BI-FM & 0.7400 & -0.38 & -0.32 & 0.55 & 0.25 & 1.00 & & & & \\
\hline BI-VM & 0.7633 & -0.30 & -0.32 & 0.40 & 0.43 & 0.54 & 1.00 & & & \\
\hline SK-A & 0.6000 & 0.01 & -0.09 & -0.01 & 0.04 & 0.00 & 0.01 & 1.00 & & \\
\hline SK-M & 0.7333 & 0.00 & -0.14 & 0.00 & 0.06 & 0.00 & 0.02 & 0.67 & 1.00 & \\
\hline U-PO & 0.6375 & 0.28 & 0.21 & -0.19 & -0.13 & -0.11 & -0.09 & 0.00 & -0.04 & 1.00 \\
\hline $\begin{array}{ll}\text { Note: } \\
\text { - } & \text { RISK-A is } \\
\text { - } & \text { RISK-M is } \\
\text { - } & \text { A-FM is } \\
\text { - } & \text { A-VM is } \\
\text { - } & \text { BI-FM is I } \\
\text { - } & \text { BI-VM is } \\
\text { - } & \text { SK-A is S } \\
\text { - } & \text { SK-M is S } \\
\text { - } & \text { U-Op is U }\end{array}$ & $\begin{array}{l}\text { erceived } \\
\text { erceived } \\
\text { titude tow } \\
\text { titude tow } \\
\text { ention to } \\
\text { tention to } \\
\text { jective } \mathrm{Kn} \\
\text { jective } \mathrm{Kr} \\
\text { efulness o }\end{array}$ & $\begin{array}{l}\text { isk of Flyi } \\
\text { isk of Vis } \\
\text { ards Flying } \\
\text { ards Visiti } \\
\text { ly Malays } \\
\text { Visit Mala } \\
\text { owledge a } \\
\text { owledge a } \\
\text { Public Op }\end{array}$ & $\begin{array}{l}\text { ng Malaysi } \\
\text { ting Malay } \\
\text { Malaysia } \\
\text { ng Malaysi } \\
\text { ia Airlines } \\
\text { ysia } \\
\text { bout Aviati } \\
\text { bout Malay } \\
\text { inion }\end{array}$ & $\begin{array}{l}\text { a Airline } \\
\text { sia } \\
\text { Airlines } \\
\text { a } \\
\text { lon } \\
\text { ysia }\end{array}$ & & & & & & \\
\hline
\end{tabular}

Based on the above results, it is reasonable to conclude that the measurement model is acceptable. The structural model results are discussed in the next part.

\subsection{Structural Model Results}

The structural model specifies the causal relations among the latent variables, and describes the causal effects and the amount of unexplained variance. The initial matter, however, is whether or not the maximum likelihood estimates for the conceptual model provide a satisfactory fit to the data.

\subsubsection{Model Fit}

The chi-square value $(\chi 2284=723.55, \mathrm{p}=0.0)$ indicated that the conceptual model did not adequately account for the relationship between the observed sample covariance and the hypothetical population covariance. Since it is generally agreed that $\chi 2$ should be used as a guide rather than an absolute index of fit $[66,68,69]$, other diagnostics are examined. Bentler and Bonett's [70] normed fit index (NFI), Bentler's [71] comparative fit index (CFI), and Bollen's [72] incremental fit index (IFI), which are fit indices measuring how much better the model fits compared to a baseline model, were used to assess the model fit.

According to Bentler and Bonett's [70] normed fit index, Bentler's [71] comparative fit index, and Bollen's [49] incremental fit index, the model had marginally acceptable fit. Specifically, the NFI, CFI, and IFI were $0.92,0.95$, and 0.95 , respectively. Since the model fit can be considered as marginally adequate, the structural parameter estimates are discussed next.

\subsubsection{Hypothesis Testing}

The following hypotheses were proposed in this study: intention to visit Malaysia is positively affected by intention to fly Malaysia Airlines (H12) and attitude toward visiting Malaysia (H9), which is, in turn, negatively affected by perceived risk of visiting Malaysia (H7) and positively affected by attitude toward flying Malaysia Airlines (H11). Intention to fly Malaysia Airlines is positively affected by attitude toward flying Malaysia Airlines (H8), which is in turn, negatively affected by perceived risk of flying Malaysia Airlines (H6). Perceived risk of flying Malaysia Airlines is negatively affected 
by subjective knowledge about aviation (H1) and positively affected by usefulness of public opinion (H2). Finally, perceived risk of visiting Malaysia is negatively affected by subjective knowledge about Malaysia (H3) and attitude toward flying Malaysia Airlines (H10), and positively by usefulness of public opinion (H4) and perceived risk of flying Malaysia Airlines (H5).

Results show that all of the hypotheses except $\mathrm{H} 1(\gamma 1,1=0.015, \mathrm{p}>0.10)$ and $\mathrm{H} 4(\gamma 2,3=0.038$, $\mathrm{p}>0.10$ ) were supported. Specifically, it is found that Intention to visit Malaysia is positively affected by intention to fly Malaysia Airlines $(\beta 6,5=0.48, p=0.00)$ and attitude toward visiting Malaysia $(\beta 6,4=0.43, p=0.00)$, which is, in turn, negatively affected by perceived risk of visiting Malaysia $(\beta 4,2=-0.41, p=0.00)$ and positively affected by attitude toward flying Malaysia Airlines $(\beta 4,3=0.25$, $p=0.00$ ). Perceived risk of visiting Malaysia is negatively affected by subjective knowledge about Malaysia $(\gamma 2,2=-0.12, p<0.05)$ and attitude toward flying Malaysia Airlines $(\beta 2,3=-0.43, p=0.00)$, and positively by perceived risk of flying Malaysia Airlines $(\beta 2,1=0.28, p=0.00)$. Intention to fly Malaysia Airlines, on the other hand, is positively affected by attitude toward flying Malaysia Airlines $(\beta 5,3=0.85, p=0.00)$, which is in turn, negatively affected by perceived risk of flying Malaysia Airlines $(\beta 3,1=-0.49, p=0.00)$. Finally, perceived risk of flying Malaysia Airlines is positively affected by usefulness of public opinion $(\gamma 1,3=0.34, \mathrm{p}=0.0)$. Table 4 shows the structural model results.

Table 4. Structural model results.

\begin{tabular}{|c|c|c|c|c|c|c|}
\hline \multirow{2}{*}{ Independent Construct } & \multicolumn{6}{|c|}{ Dependent Construct } \\
\hline & $\begin{array}{l}\text { Perceived Risk of } \\
\text { Flying Malaysia } \\
\text { Airlines }\end{array}$ & $\begin{array}{l}\text { Perceived Risk of } \\
\text { Visiting Malaysia }\end{array}$ & $\begin{array}{l}\text { Attitude toward } \\
\text { Flying Malaysia } \\
\text { Airlines }\end{array}$ & $\begin{array}{l}\text { Attitude toward } \\
\text { Visiting Malaysia }\end{array}$ & $\begin{array}{c}\text { Intention to Fly } \\
\text { Malaysia } \\
\text { Airlines }\end{array}$ & $\begin{array}{c}\text { Intention to } \\
\text { Visit Malaysia }\end{array}$ \\
\hline Subjective Knowledge about Aviation & $0.015^{\text {n.s. }}$ & - & - & - & - & - \\
\hline Subjective Knowledge about Malaysia & - & $-0.12^{\mathrm{b}}$ & - & - & - & - \\
\hline Usefulness of Public Opinion & $0.34^{\mathrm{a}}$ & $0.052^{\text {n.s. }}$ & - & - & - & - \\
\hline Perceived Risk of Flying Malaysia Airlines & - & $0.28^{\mathrm{a}}$ & $-0.49^{\mathrm{a}}$ & - & - & - \\
\hline Perceived Risk of Visiting Malaysia & - & - & - & $-0.41^{\mathrm{a}}$ & - & - \\
\hline Attitude toward Flying Malaysia Airlines & - & $-0.43^{\mathrm{a}}$ & - & $0.25^{\mathrm{b}}$ & $0.85^{\mathrm{a}}$ & - \\
\hline Attitude toward Visiting Malaysia & - & - & - & - & - & $0.43^{\mathrm{a}}$ \\
\hline Intention to Fly Malaysia Airlines & - & - & - & - & - & $0.48^{\mathrm{a}}$ \\
\hline $\mathrm{R}^{2}$ & 0.079 & 0.42 & 0.48 & 0.34 & 0.3 & 0.38 \\
\hline Chi-square & \multicolumn{6}{|c|}{723.55} \\
\hline Degree of freedom & \multirow{2}{*}{\multicolumn{6}{|c|}{$\begin{array}{c}284 \\
0\end{array}$}} \\
\hline$p$-value & & & & & & \\
\hline NFI & \multicolumn{6}{|c|}{0.92} \\
\hline CFI & \multirow{2}{*}{\multicolumn{6}{|c|}{0.95}} \\
\hline IFI & & & & & & \\
\hline
\end{tabular}

\section{Conclusions and Implications}

This study is an attempt to investigate the process by which the air disaster of a national airline affects tourists' attitude and intention to fly the airline as well as attitude and intention to visit the country by proposing and empirically testing factors affecting the attitude and intention toward flying the national airline that experienced air disaster as well as attitude and intention to visit the country of origin for vacation. The theoretical contribution and managerial implications, limitations, and concluding summary are discussed below.

\subsection{Theoretical Contribution and Managerial Implications}

This study contributes to the body of knowledge by demonstrating the process by which consumers use to determine if they would fly the airline in question to the country of origin. Specifically, intention to visit the country is positively affect by intention to fly the airline and attitude toward visiting the country. The effect of perceived risk of flying the airline on attitude toward visiting the country is mediated by perceived risk of visiting the country and attitude toward visiting the country. Subjective knowledge about the country significantly reduces perceived risk about visiting the country. Finally, usefulness of public opinion significantly reduces perceived risk of flying the airline.

Although the empirical findings in this study might be or might not be able to generalize to explain the effect of other types of disaster (e.g., earthquake, kidnapping of tourists) on tourists' 
willingness to visit a country, the conceptual framework used in this study (i.e., dual mediation model) might be useful in conceptualizing the effect of the disaster on tourists' willingness to visit country in question.

From this study, there are insights for managerial implications for both the airline with air disaster(s) and the country of origin. For the airline, attitude toward flying the airline is negatively affected by perceived risk of flying the airline, which is, in turn, positively affected by perceived usefulness of public opinion. Since most published public opinions on Malaysia Airline after the air disaster are negative, perceived usefulness of public opinion increases perceived risk of flying Malaysia Airlines. As such, the airline should try to create positive public opinions about the airlines, for example, by releasing public relations regarding the improved safety and other aspects of the airline to the public on a regular basis.

For the country, perceived risk of flying the airline indirectly affects attitude toward visiting the country via attitude toward flying the airline. In other words, higher perceived risk of flying the airline reduce attitude toward flying the airline, which in turn, reduce attitude toward visiting the country. As such, the tourism authority of the company may try to disengage itself from the airline. For example, Malaysia's Tourism Authority may form strategic partnership with Chinese airlines such as Southern Airlines for trips to Malaysia. Furthermore, subjective knowledge about the country significantly reduces perceived risk of visiting the country. As such, the tourism authority of the county may focus on improving the target customers' knowledge about the country. For example, Malaysia's Tourism Authority may produce and launch TV programs and publications in both traditional and social media about Malaysia country and culture.

\subsection{Limitations}

The contributions of this study must be viewed with light of its limitations. There are a few limitations in this study. First of all, the research design of this study is sample survey, which is a correlational study. Although this research design can establish if there are significant relationships among the constructs, it cannot actually establish the causal relationship among them. The directions in the hypotheses are presumed causes and presumed effects.

Second, perceived risks were the only determinant of attitudes in this study. There can be, however, several other potential determinants of attitude toward the airline (e.g., benefits of the airline, air travel experience) and attitude toward the country (e.g., benefits of visiting the country, tourist experience, country's frequency of natural disasters) that should be added into the model in the future research.

Third, although the subjects in this study seemed to fit the profile of the target customer for vacation overseas, the sampling method was essentially judgmental sampling (i.e., the exploratory study data were collected from subjects in a city in China, and survey data were collected from subjects in China). It is likely that the findings may not be able to generalize to the whole population of potential customers. As such, the findings from this study should be applied with care. Future research may use more representative subjects (i.e., from more cities in China or from different countries where tourists did not go through such a serious air disaster as MH370).

Finally, this study is a cross-sectional study. Purchase intention was used as the surrogate variable for future behavior. Purchase intention may or may not become purchase behavior. Future research should consider the use of longitudinal study to test if purchase intention is a good predictor of purchase behavior.

\subsection{Summary}

Results show that all except two hypotheses were supported. The lack of significant negative effect of subjective knowledge about aviation on perceived risk of flying Malaysia Airlines may be due to the fact that most Chinese consumers do not perceive themselves to have any knowledge about aviation. The lack of significant positive impact of usefulness of (negative) public opinion on perceived 
risk of visiting Malaysia may be due to the fact that most published public opinions are about Malaysia Airlines rather than Malaysia.

This study is an attempt to understand a rare but significant phenomenon of air disasters by investing the process by which the air disaster of a national airline affects foreign tourists' attitude and intention to fly the airline as well as their attitude and intention to visit the country. Data from Chinese potential tourists were used to empirically test a conceptual model derived from a qualitative research and literature review. Malaysia Airlines and Malaysia were used as the case for studying the phenomenon. Although there are limitations, this study offers some theoretical contribution and managerial implications to the area of the impact of air disasters on tourism.

Author Contributions: Conceptualization, T.F., B.P., and S.P.; Formal analysis, T.F. and S.P.; Investigation, T.F., B.P., and S.P.; Writing—original draft preparation, T.F.; Writing—review and editing, T.F., B.P., S.P., and L.H.; Supervision, S.P. and L.H.; Funding acquisition, B.P.

Funding: This research was funded by "The National Natural Science Foundation of China Youth Program", grant number 71804119 .

Conflicts of Interest: The authors declare no conflict of interest.

\section{Appendix A}

Table A1. Adapted scale of construct.

\begin{tabular}{|c|c|c|}
\hline Construct & Adapted Scale & Scale Reference \\
\hline Subjective knowledge about aviation & $\begin{array}{l}\text { 1. I know pretty much about aviation knowledge. } \\
\text { 2. I do not feel very knowledgeable about aviation. * } \\
\text { 3. Among my circle of friends, I'm one of the } \\
\text { "experts" on aviation knowledge. }\end{array}$ & Flynn and Goldsmith (1999) \\
\hline Subjective knowledge about Malaysia & $\begin{array}{l}\text { 1. I know pretty much about Malaysia. } \\
\text { 2. I do not feel very knowledgeable about Malaysia. * } \\
\text { 3. Among my circle of friends, I'm one of the } \\
\text { "experts" on Malaysia. }\end{array}$ & Flynn and Goldsmith (1999) \\
\hline Usefulness of public opinion & $\begin{array}{l}\text { 1. I think public opinion about Malaysia Airlines } \\
\text { is useful. } \\
\text { 2. Public opinions about Malaysia Airlines can help } \\
\text { me save time effectively in finding information. } \\
\text { 3. Public opinions about Malaysia Airlines can help } \\
\text { me get useful information. } \\
\text { 4. Public opinions about Malaysia Airlines can help } \\
\text { me get information quickly. }\end{array}$ & Davis (1989) \\
\hline Perceived risk of flying Malaysian airlines & $\begin{array}{l}\text { 1. I do not trust that Malaysian airlines will be secure. } \\
\text { 2. I do not trust that Malaysian airlines will provide } \\
\text { me with a safe flight. }\end{array}$ & Forsythe and Shi (2003) \\
\hline Perceived risk of visiting Malaysia & $\begin{array}{l}\text { 1. I do not trust that Malaysia will be secure. } \\
\text { 2. I do not trust that Malaysia will provide me with a } \\
\text { safe tourism environment. }\end{array}$ & Forsythe and Shi (2003) \\
\hline Attitude toward flying Malaysian Airlines & $\begin{array}{l}\text { 1. My overall feeling toward flying Malaysia Airlines } \\
\text { is anger.* } \\
\text { 2. My overall feeling toward flying Malaysia Airlines } \\
\text { is distress.* } \\
\text { 3. My overall feeling toward flying Malaysia Airlines } \\
\text { is fear.* }\end{array}$ & Jang and Namkung (2009) \\
\hline Attitude toward visiting Malaysia & $\begin{array}{l}\text { 1. My overall feeling toward visiting Malaysia is } \\
\text { anger.* } \\
\text { 2. My overall feeling toward visiting Malaysia is } \\
\text { distress.* } \\
\text { 3. My overall feeling toward visiting Malaysia is } \\
\text { fear.* }\end{array}$ & Jang and Namkung (2009) \\
\hline
\end{tabular}


Table A1. Cont.

\begin{tabular}{llll}
\hline \multicolumn{1}{c}{ Construct } & \multicolumn{1}{c}{ Adapted Scale } & \multicolumn{1}{c}{ Scale Reference } \\
\hline Intention to fly Malaysian Airlines & $\begin{array}{l}\text { 1. } \\
\text { 2. }\end{array}$ & $\begin{array}{l}\text { I predict I will fly Malaysia Airlines in the future. } \\
\text { I would fly Malaysia Airlines rather than any } \\
\text { other airline. } \\
\text { If everything goes as I think, I will plan to fly } \\
\text { Malaysia Airlines in the future. }\end{array}$ & Jalilvand et al. (2012) \\
\hline Intention to visit Malaysia & $\begin{array}{l}\text { 1. } \\
\text { 2. }\end{array}$ & $\begin{array}{l}\text { I predict I will visit Malaysia in the future. } \\
\text { tourism destination. }\end{array}$ & $\begin{array}{l}\text { If everything goes as I think, I will plan to visit } \\
\text { Malaysia in the future. }\end{array}$ \\
\hline
\end{tabular}

Note: * is reversed score.

\section{References}

1. Aviation benefits beyond border (n.d.). Available online: https://aviationbenefits.org/social-development/ tourism/ (accessed on 24 November 2018).

2. Lu, H. Interview: Malaysia ramps up efforts to attract Chinese tourists. Xinhuanet. 2017. Available online: http:/ / www.xinhuanet.com/english/2017-10/13/c_136676857.htm (accessed on 13 October 2017).

3. Toursim becomes Malaysia's sixth economic pillar. 2015. Available online: http://my.xinhuanet.com/201508/04/c_128090838.htm (accessed on 12 February 2019).

4. Jang, B. After two aviation disasters, Malaysia Airlines will struggle to survive. The Globe and Mail. 2014. Available online: https:/ / www.theglobeandmail.com/news/world/after-two-aviation-disasters-malaysiaairlines-will-struggle-to-survive/article19669404/ (accessed on 17 July 2018).

5. Zeithaml, V.A. Consumer perceptions of price, quality, and value: A means-end model and synthesis of evidence. J. Mark. 1988, 52, 2-22. [CrossRef]

6. MacKenzie, S.B.; Lutz, R.J.; Belch, G.E. The role of attitude toward the ad as a mediator of advertising effectiveness: A test of competing explanations. J. Mark. Res. 1986, 23, 130-143. [CrossRef]

7. Lutz, R.J.; Swasy, J.L. Integrating cognitive structure and cognitive response approaches to monitoring communications effects. Adv. Consum. Res. 1977, 4, 363-371.

8. Petty, R.E.; Cacioppo, J.T. The elaboration likelihood model of persuasion. Adv. Exp. Soc. Psychol. 1986, 19, 123-205. [CrossRef]

9. Wongpitch, S.; Minakan, N.; Powpaka, S.; Laohavichien, T. Effect of corporate social responsibility motives on purchase intention model: An extension. Kasetsart J. Soc. Sci. 2016, 37, 30-37. [CrossRef]

10. Homer, P.M. The mediating role of attitude toward the ad: Some additional evidence. J. Mark. Res. 1990, 27, 78-86. [CrossRef]

11. Karson, E.J.; Fisher, R.J. Predicting intentions to return to the Web site: Extending the dual mediation hypothesis. J. Interact. Mark. 2005, 19, 2-14. [CrossRef]

12. López, I.; Ruiz, S. Explaining website effectiveness: The hedonic-utilitarian dual mediation hypothesis. Electron. Commer. Res. Appl. 2011, 10, 49-58. [CrossRef]

13. Goldsmith, R.E.; Lafferty, B.A.; Newell, S.J. The impact of corporate credibility and celebrity on consumer reaction to advertisements and brands. J. Advert. 2000, 29, 43-54. [CrossRef]

14. Alba, J.W. The effects of product knowledge on the comprehension, retention, and evaluation of product information. Adv. Consum. Res. 1983, 10, 577-580. [CrossRef]

15. Brucks, M. The effects of product class knowledge on information search behavior. J. Consum. Res. 1985, 12, 1-16. [CrossRef]

16. Sujan, M. Consumer knowledge: Effects on evaluation strategies mediating consumer judgments. J. Consum. Res. 1985, 12, 31-46. [CrossRef]

17. Rao, A.R.; Monroe, K.B. The moderating effect of prior knowledge on cue utilization in product evaluations. J. Consum. Res. 1988, 15, 253-264. [CrossRef]

18. Klerck, D.; Sweeney, J.C. The effect of knowledge type on consumer perceived risk and adoption of genetically modified foods. Psychol. Mark. 2007, 24, 171-193. [CrossRef] 
19. Hadar, L.; Sood, S.; Fox, C.R. Subjective knowledge in consumer financial decisions. J. Mark. Res. 2013, 50, 303-316. [CrossRef]

20. Oh, K.; Abraham, L. Effect of knowledge on decision making in the context of organic cotton clothing. Int. J. Consum. Stud. 2016, 40, 66-74. [CrossRef]

21. Park, C.W.; Mothersbaugh, D.L.; Feick, L. Consumer knowledge assessment. J. Consum. Res. 1994, $21,71-82$. [CrossRef]

22. Flynn, L.R.; Goldsmith, R.E. A short, reliable measure of subjective knowledge. J. Bus. Res. 1999, 46, 57-66. [CrossRef]

23. Cole, C.; Gaeth, G.; Chakraborty, G.; Levin, I. Exploring the relationships among self-reported knowledge, objective knowledge, product usage, and consumer decision making. In Advances in Consumer Research; Sherry, J.F., Sternthal, B., Eds.; Association for Consumer Research: Provo, UT, USA, 1992; p. 191, ISBN 00989258.

24. Raju, P.S.; Lonial, S.C.; Mangold, W.G. Differential effects of subjective knowledge, objective knowledge, and usage experience on decision making: An exploratory investigation. J. Consum. Psychol. 1995, 4, 153-180. [CrossRef]

25. Selnes, F.; Gronhaug, K. Subjective and objective measures of product knowledge contrasted. Adv. Consum. Res. 1986, 13, 67-71.

26. Jin, H.J.; Han, D.H. Interaction between message framing and consumers' prior subjective knowledge regarding food safety issues. Food Policy 2014, 44, 95-102. [CrossRef]

27. Fiske, C.A.; Luebbehusen, L.A.; Miyazaki, A.D.; Urbany, J.E. The relationship between knowledge and search: It depends. In Advances in Consumer Research; Allen, C.T., John, D.R., Eds.; Association for Consumer Research: Provo, UT, USA, 1994; Volume 21, pp. 43-50, ISBN 17444798.

28. Zhang, L.; Chen, L.; Wu, Z.; Zhang, S.; Song, H. Investigating young consumers' purchasing intention of green housing in China. Sustainability 2018, 10, 1044. [CrossRef]

29. Moorman, C.; Diehl, K.; Brinberg, D.; Kidwell, B. Subjective knowledge, search locations, and consumer choice. J. Consum. Res. 2004, 31, 673-680. [CrossRef]

30. Perrouty, J.F.; d'Hauteville, F.; Lockshin, L.S. The influence of wine attributes on region of origin equity: An analysis of the moderating effect of consumer's perceived expertise. Agribusiness 2006, 22, 323-341. [CrossRef]

31. Rodrigues, J.F.; Pereira, R.C.; Silva, A.A.; Mendes, A.O.; Carneiro, J.S. Sodium content in foods: Brazilian consumers' opinions, subjective knowledge and purchase intent. Int. J. Consum. Stud. 2017, 41, 735-744. [CrossRef]

32. Blackwell, R.D.; Miniard, P.W.; Engel, J.F. Consumer Behavior, 9th ed.; Harcourt College Publishers: Fort Worth, TX, USA, 2001; ISBN 9780324271973.

33. East, R.; Hammond, K.; Lomax, W. Measuring the impact of positive and negative word of mouth on brand purchase probability. Int. J. Res. Mark. 2008, 25, 215-224. [CrossRef]

34. Paswan, A.K.; Kantamneni, S.P. Public opinion and franchising in an emerging market. Asia Pac. J. Mark. Logist. 2004, 16, 46-61. [CrossRef]

35. Sparks, B.A.; Browning, V. The impact of online reviews on hotel booking intentions and perception of trust. Tour. Manag. 2011, 32, 1310-1323. [CrossRef]

36. Herrero, A.; Martín, H.S.; Hernández, J.M. How online search behavior is influenced by user-generated content on review websites and hotel interactive websites. Int. J. Contemp. Hosp. Manag. 2015, 27, 1573-1597. [CrossRef]

37. Davis, F.D. Perceived usefulness, perceived ease of use, and user acceptance of information technology. MIS Quarterly 1989, 13, 319-340. [CrossRef]

38. Davis, F.D. User acceptance of information technology: System characteristics, user perception, and behavioral impacts. Int. J. Man-Mach. Stud. 1993, 38, 475-487. [CrossRef]

39. Valkenburg, P.M.; Peter, J. Preadolescents' and adolescents' online communication and their closeness to friends. Dev. Psychol. 2007, 43, 267-277. [CrossRef] [PubMed]

40. Pthanasthassis, A.; Knolle, F. Exploring the adoption and processing of online holiday reviews: A grounded theory approach. Tour. Manag. 2011, 32, 215-224. [CrossRef]

41. Casaló, L.V.; Flavián, C.; Guinalíu, M.; Ekinci, Y. Avoiding the dark side of positive online consumer reviews: Enhancing its usefulness for high risk-averse travelers. J. Bus. Res. 2015, 68, 1829-1835. [CrossRef] 
42. Bauer, R.A. Consumer behavior as risk taking. In Proceedings of the 43rd National Conference of the American Marketing Association, Chicago, IL, USA, June 1960; pp. 389-398.

43. Mitchell, V.W. Consumer perceived risk: Conceptualisations and models. Eur. J. Mark. 1999, 33, $163-195$. [CrossRef]

44. Antony, S.; Lin, Z.; Xu, B. Determinants of escrow service adoption in consumer-to-consumer online auction market: An experimental study. Decis. Support Syst. 2006, 42, 1889-1900. [CrossRef]

45. Pappas, N. Marketing strategies, perceived risks, and consumer trust in online buying behaviour. J. Retail. Consum. Serv. 2016, 29, 92-103. [CrossRef]

46. Jacoby, J.; Kaplan, L.B. The Components of perceived risk. In Proceedings of the Third Annual Conference of the Association for Consumer Research, Chicago, IL, USA, November 1972; pp. 382-393.

47. Mitchell, A.A.; Olson, J.C. Are product attribute beliefs the only mediator of advertising effects on brand attitude? J. Mark. Res. 1981, 18, 318-332. [CrossRef]

48. Ajzen, I.; Fishbein, M. Understanding Attitudes and Predicting Social Behavior; Prentice-Hall: Englewood Cliffs, NJ, USA, 1980; ISBN 9780139364358.

49. Fishbein, M.; Ajzen, I. Belief, Attitude, Intention, and Behavior; Addison-Wesley: Reading, MA, USA, 1975; ISBN 0201020890.

50. Wu, P.C.; Wang, Y.C. The influences of electronic word-of-mouth message appeal and message source credibility on brand attitude. Asia Pac. J. Mark. Logist. 2011, 23, 448-472. [CrossRef]

51. Keller, K.L.; Lehmann, D.R. Brands and branding: Research findings and future priorities. Mark. Sci. 2006, 25, 740-759. [CrossRef]

52. Kudeshia, C.; Kumar, A. Social eWOM: Does it affect the brand attitude and purchase intention of brands? Manag. Res. Rev. 2017, 40, 310-330. [CrossRef]

53. Summers, T.A.; Belleau, B.D.; Xu, Y. Predicting purchase intention of a controversial luxury apparel product. J. Fash. Mark. Manag. 2006, 10, 405-419. [CrossRef]

54. Abzari, M.; Ghassemi, R.A.; Vosta, L.N. Analysing the effect of social media on brand attitude and purchase intention: The case of Iran Khodro company. Procedia-Soc. Behav. Sci. 2014, 143, 822-826. [CrossRef]

55. Ariffin, S.K.; Mohan, T.; Goh, Y.N. Influence of consumers' perceived risk on consumers' online purchase intention. J. Res. Interact. Mark. 2018, 12, 309-327. [CrossRef]

56. Ting, H.; de Run, E.C. Attitude towards advertising: A young generation cohort's perspective. Asian J. Bus. Res. 2015, 5, 69-82. [CrossRef]

57. Shen, G.C.C. Users' adoption of mobile applications: Product type and message framing's moderating effect. J. Bus. Res. 2015, 68, 2317-2321. [CrossRef]

58. Duarte, P.; Amaro, S. An integrative model of consumers' intentions to purchase travel online. Tour. Manag. 2015, 46, 64-79. [CrossRef]

59. Loehlin, J.C. Latent Variable Models: An Introduction to Factor, Path, and Structural Equation Analysis; Routledge: New York, NY, USA, 2004; ISBN 9780805849103.

60. Forsythe, S.M.; Shi, B. Consumer patronage and risk perceptions in Internet shopping. J. Bus. Res. 2003, 56, 867-875. [CrossRef]

61. Jang, S.; Namkung, Y. Perceived quality, emotions, and behavior Intentions: Application of an extended Mehrabian-Russell model to restaurants. J. Bus. Res. 2009, 62, 451-460. [CrossRef]

62. Jalilvand, M.R.; Samiei, N.; Dini, B.; Manzari, P.Y. Examining the structural relationships of electronic word of mouth, destination image, tourist attitude toward destination and travel intention: An integrated approach. J. Destin. Mark. Manag. 2012, 1, 134-143. [CrossRef]

63. Jöreskog, K.G.; Sörbom, D. PRELIS: A Program for Multivariate Data Screening and Data Summarization, 2nd ed.; Scientific Software, Inc.: Chicago, IL, USA, 1988; ISBN 1563211858.

64. Jöreskog, K.G.; Sörbom, D. Lisrel 8: Structural Equation Modeling with the SIMPLIS Command Language; Scientific Software, Inc.: Chicago, IL, USA, 1993; ISBN 0805814418.

65. Powpaka, S. How market orientation affects female service employees in Thailand. J. Bus. Res. 2006, 59, 54-61. [CrossRef]

66. Fornell, C.; Larcker, D.F. Evaluating structural equation models with unobservable variables and measurement error. J. Mark. Res. 1981, 18, 39-50. [CrossRef]

67. Nunnally, J.C. Psychometric Theory; McGraw-Hill: New York, NY, USA, 1978; ISBN 9781441910059. 
68. Bagozzi, R. Attitudes, intentions, and behavior: A test of some key hypotheses. J. Personal. Soc. Psychol. 1981, 41, 607-627. [CrossRef]

69. Bearden, W.O.; Sharma, S.; Teel, J.E. Sample size effects upon Chi-Square and other statistics used in evaluating causal models. J. Mark. Res. 1982, 19, 425-430. [CrossRef]

70. Bentler, P.M.; Bonett, D.G. Significance tests and goodness of fit in the analysis of covariance structures. Psychol. Bull. 1980, 88, 588-606. [CrossRef]

71. Bentler, P.M. Comparative fit indexes in structural models. Psychol. Bull. 1990, 107, 238-246. [CrossRef] [PubMed]

72. Bollen, K.A. A new incremental fit index for general structural equation models. Sociol. Methods Res. 1989, 17, 303-316. [CrossRef]

(C) 2019 by the authors. Licensee MDPI, Basel, Switzerland. This article is an open access article distributed under the terms and conditions of the Creative Commons Attribution (CC BY) license (http:/ / creativecommons.org/licenses/by/4.0/). 